\title{
Conceptualization of business excellence model with a grand theory approach
}

\author{
Professor Dr. Sorush Niknamian \\ Board Member of Weston A Price Foundation, Washington DC, USA \\ Wmail: so.niknamian@gmail.com
}

\begin{abstract}
Purpose - This paper aims to conceptualize business excellence model and identify its variables and indicators.

Design/methodology/approach - The philosophical foundations of this critical with the school of symbolic interaction and the strategy of grand theory deal with open, axial and selective coding; whose output is a new concept. Data collection of this paper is based on documentation studies on excellence models. The population under study more specifically includes the models existing in prestigious journals and magazines with theoretical sampling logic in order to reach theoretical saturation. To measure validity, CASP was applied and to assess reliability, two encoders were used.

Findings - Reliability was calculated to be 0.869 through the agreement between two encoders and Kappa coefficient for 102 samples; the reliability was good. For analysis, MAXQDA software has been employed. Out of 102 conceptual excellence models under investigation in the coding step, 869 concepts or open codes were obtained. Common basic codes were divided into 50 major categories in terms of meaning, which, in the selective coding step, led to the creation of five dimensions with the names of people, market, work, management and the underlying factors.

Originality/value - The conducted study is a small step towards the extraction of indicators and concepts of business excellence from 102 classic models. Thus, interested researchers and scholars are recommended to benefit from the rich resources of articles to extract business excellence theories with a grand theory approach.
\end{abstract}

Keywords: Business excellence, grand theory, meta-synthesis, text analysis 


\section{Introduction}

Excellence means evolution. Excellence means the beauty of flowers. An individual reaches excellence through work and activity. In the dictionary, excellence means quality with the highest order (Dahgaard, 2007). In the management literature, the term quality has different meanings and definitions, including excellence, value, suitable for use, compliance with features and attributes, compliance with requirements, flawless, meeting the customer expectations or more than that. These definitions are various aspects of quality and excellence. In 1987, some writers and thinkers like Deming, Ishikawa, Peters and Lamia supported the role and importance of quality as the basis and cornerstone of excellence. Other writers and experts, such as Juran and Crosby in 1990, focused on direct business needs. Jensen states in 2000 that companies should have a unique and value goal. Shaffer and Thompson argued in 1992 for the role of excellence in obtaining financial results (Sharma \& Talwar ,2007.(

The main purpose of the present article is to add to the scope and level of knowledge existing in the area of "business excellence" because by examining the articles in Persian and Latin and focusing on the business excellence model and searching the citation databases and search engines and by filtering on the title, an abstract with the keyword business excellence is published. In the search results in this regard, we will be faced with numerous studies. The number of studies conducted is one of the criteria for selecting the research topic and the large number of research shows that there are questions and full information about the subject, and advanced statistical analysis programs can easily be used, but the situation is much different from the initial judgment since by studying the abstract and conceptual models and keywords of the research carried out, it can be concluded that the term business has been widely used in different sciences especially the management science and its subcategories.

But this term does not adequately address the meaning of business and has been used frequently in every branch of science in which researchers have provided and evaluated models. For example, when the general definition of quality excellence model of the European Union is reviewed, the term business is used in the title. But its approach focuses more on organizational excellence, and other models are also in the same way. However, excellence in any form leads to the development of business. Even many of the indicators of existing models can be used in businesses and lead to continuous improvement.

The maturity model is a useful way to evaluate the processes and, in general, the level of business maturity. However, it is not easy to find a suitable maturity model. In common models, there is no shortage of a maturity model for a specific area in the management process of lean six sigma, which should be considered in the development of models (Albliwi, 2014).

There are different models that can help the company for entrepreneurship, mostly focused on typical TQM critical success factors, such as staff, customer, leadership, process, management and so on, and a few frameworks pay attention to complexity and dynamism. In most of the models, what needs to be done for excellence is stated, but it is not explained how to do it. Research shows that $70 \%$ of the failure of excellence models in implementing special operating structures depends on the type and severity of that change. A solution to remove the challenges is the integration of excellence models with respect to dynamic and complex processes in order to guarantee sustainable results for all stakeholders (Amir, 2013). 
In excellence models, most of the strategies are understood and applied with a static environment perspective and the strategy should be integrated in order to produce positive and sustainable results, which the gap in past research is evident (Balbastre, 2011).

Despite the widespread use of excellence models as a self-assessment tool in the past two decades, little is known about the basic logic that is important following the promotion of organizations to their criteria and it is not clear whether these scores are consistent with business realities. EFQM model criteria weight in Europe (which is directly perceived by managers and is obtained through statistical analysis) is different from the values given by the advertising organization, and managers should define their weight for each element with regard to the features of their own company (Gómez, 2016).

On the other hand, after studying the common business excellence models and their dimensions, the question/hypothesis of this paper was proposed. In this article, the answer to the following question has been of particular concernWhat a :re the variables and indicators of a business excellence model?

\section{Research background}

The first global business excellence model was the Deming Award which was introduced in 1951 by Japan Scientific and Engineering Association. The next award, titled "Certified Executive Association", was introduced by the Canadian National Quality Institute in 1984. Afterwards, Malcolm Baldrige Quality Award was presented in 1987 by the US National Institute of Standards and Technology and then, Australian Quality Award was introduced in 1988. International Trade Development Institute introduced ISO 9000 standard in 1987 as an international standard for recognizing quality management standard. The European Quality Award was created according to the European Quality Management Foundation's model in 1990. Most of them were established based on the Deming model and quality in 1991. Along with European countries, several countries in Asia also established quality awards in 1990. Most of them used the Deming model and quality as reference. For instance, qualitative models were designed by India in 1994, Singapore and Japan in 1995, the Philippines in 1997, Fiji in 1998 and Thailand in 2001. Malcolm Baldrige excellence models from the US, European foundation for quality management model and Deming Award model from Japan were globally recognized and introduced as the mother of other models and awards (Cyrlee, 2005).

Rastgar (2016) demonstrated in a study that B2B brand equity, social responsibility and reputation of the provider, brand preference and repurchase intention have positive effects on brand performance. The reputation and social responsibility of the provider also have a significant positive impact on $\mathrm{B} 2 \mathrm{~B}$ brand equity. Further, the relationships between the social responsibility and reputation of the provider, brand equity and brand preference and brand preference and repurchase intention were significant and positive. Domestic suppliers can use the research findings for branding and managing their brand performance in domestic and international industrial markets.

Khodadad Hosseini (2015) argued in a study that the organization's market performance improvement model based on a combination of effective dynamic capabilities such as IT competency, entrepreneurial alertness, absorption capacity, operational agility and market orientation have been provided and tested in Iran Electronics Industry to improve market performance. This model has been created based on four areas of management literature, i.e. 
strategic management literature related to dynamic capabilities, literature related to the field of marketing, entrepreneurship and literature related to information technology. The results obtained from the statistical sample confirm the above model. Thus, it can be concluded that the combination provided from dynamic capabilities helps to improve market performance.

Akbari Emami (2015) showed in a study that the successful strategy implementation model explains the factors affecting the successful implementation of strategies and also their interactions so that successful implementation which is a function of the behavioral context is considered as the causal condition for the occurrence of performance-based behavioral competencies and the power for strategy implementation along with intra-organizational factors and relative stability of the governing context will lead to the final outcome, i.e. the realization of perspectives and goals, consensus and organizational agility.

Jahanian (2015) demonstrated in a study that the elements of Internet marketing mix are classified in two dimensions of common mix and Internet mix. The result of the qualitative stage was determined with regard to factor load and coefficient of determination of each factor. Accordingly, Internet mix elements are more important than common mix elements. Output of the research qualitative stage is the conceptual model of internet marketing mix, which embraces all dimensions, indicators and factors of internet marketing mix. At the end of the qualitative stage, a questionnaire was extracted based on the research model and was used as the basis of quantitative data collection. Output of the quantitative stage is the Internet marketing mix model which consists of dimensions, factors and components of the model together with their factor load. This model was tested using valid statistical tests and enjoys acceptable factor validity and fit indices. Madani (2015) conducted a study and revealed that explaining 25 categories in the form of 8 groups includes inspirational and perfectionist leadership, insight marketing, creative and innovative thinking, employee empowerment, deep recognition of customers, discovery of customer needs, active management of customers' changing preferences, relationship-based marketing, sustainability marketing, internal marketing, customer empowerment, dynamic competition, provision of superior services and multifaceted value creation for customers, knowledgeable customer, customer mental development, enhanced customer's citizenship behavior, perception of justice from the perspective of customers, brand credibility, customer support, creating corporate social capital, creating intellectual capital in organizations, building social trust, increasing the quality of life and creating social capital in society, which have been presented in the form of a paradigmatic model.

Mandana (2014) observed in a study that active organizations in the field of software production and development are faced with great environmental changes due to the high level of competition, customers' need to personalize products, the pressure to reduce production time and the high speed of growth of emerging technologies. The need for the survival of these organizations in a dynamic environment is the use of agile software production and development methodology for faster adaptation of business processes and activities to the environment. Successful use of this methodology, especially in the analysis phase in which analysts engage in recognizing the customer's requirements and determining the architecture of the system, empowers the organization in providing products at the right time and in this way plays a crucial role for the organization from the perspective of value creation. Accordingly, in the present study, factors influencing the success of this methodology were identified after examining the research literature. Next, attempt was made to find those factors that are effective in the success of analyzing this methodology and product maintenance phase with regard to the role of analysis in product maturity 
stage in which the software is deployed in client organization and is applied by users. Based on the research data analysis, it is suggested that the factors affecting the success of the agile methodology analysis phase in software maturity stage be classified in 7 categories: Individualcustomer, individual-analyst, interpersonal, organizational, managerial, process and technology.

Afjeh (2014) indicated in a study that the organizational justice model with an Islamic approach comprises 35 concepts (indicators) such that the identified concepts have been divided into three (variable) categories of distributive justice, procedural justice, and interactional justice.

Asgarnezhad Nouri (2014) reported in a study that with the application of the most consistent techniques for improving service quality, it is still not possible to completely eliminate the possibility of service failures. Minimizing the time gap between understanding service failures and compensating for shortcomings faced by customers in the process of service supply with the minimum cost is one of the requirements of responsive companies in a competitive environment. In the present paper, consideration has been given to modeling the response time of service restoration so that it includes profit optimization of service restoration chain on one hand and satisfaction of the customers facing failure on the other, and profit optimization conflict between the whole chain of service restoration and local profit of sectors or companies existing in the service failure restoration chain with the "two-level planning" approach has been modeled. The main sector or company for service restoration as the leader and, at the lower level, sectors or companies existing in the service failure restoration chain as the follower play the role of local decision-maker. Therefore, a participatory optimal decision is made between companies existing in the service failure restoration chain, in which the main company of the service failure restoration chain as the leader interactively negotiates with other companies in the service failure restoration chain. In this article, a meta-heuristic hybrid algorithm was developed to solve the relevant model and with an applied example, the method of analyzing the results was also examined.

Hoseini Qasr (2014) suggested in a study that most of the issues were allocated to three subjects: the role of education in entrepreneurship and employment, concepts and presentation of conceptual models, frameworks and entrepreneurship factors descriptively and personality traits and entrepreneurial skills. Hence, the methodology used in studies is mostly quantitative and of survey and documentary research type.

Saryazdi (2014) performed a study and announced that out of the dimensions of knowledge management, investment in knowledge management technology can be more effective in university performance. Additionally, the coding strategy is more effective than the personalization strategy for universities. Finally, an overall approach was presented to generalize policies, which is a good guide for all organizations that invest in knowledge management. After assessing and identifying the stronger dimension of knowledge management in the organization, this approach introduces a more appropriate strategy of knowledge management for that organization. If the organization is stronger in each of the dimensions of knowledge management process, knowledge management technology or knowledge management measurement, application of the coding strategy is more effective and if it is stronger in knowledge management culture or knowledge management leadership, personalization strategy is more effective. In a study conducted by Abbasi, it was revealed that the criterion of leadership enjoys the highest score among empowers and greatest effectiveness in other criteria, and results of service recipients enjoy the highest score among the results and greatest influence-taking from other criteria. Ultimately, to prioritize improvement projects derived from the mentioned excellence model, a hierarchical approach has been proposed. 
Arabshahi Karizi (2014) demonstrated that since it is believed that Islam is the most complete and comprehensive religion and God, as the creator of man, can better show the path of perfection and excellence to humans, in Iran and Islamic countries, one should refer to Islam and different Islamic sources to formulate a comprehensive model in this regard. In this research, we intend to provide an organizational excellence model with an Islamic approach to the extent possible by referring to Islamic sources and taking advantage of the holy Quran verses and sermons and letters and wisdom of Nahj al-Balaghah.

Hajian (2013) carried out a study and indicated that the proposed research model consisted of two dimensions of empowerer and results, 9 main criteria, 31 sub-criteria and 24 indicators related to sub-criteria of results. Then, weighting and prioritization of dimensions and criteria of the model were done through questionnaire and expert opinions and using group AHP technique and subcriteria and indicators of the model and also direct method and geometric mean calculation. In the end, one of the non-industrial research centers was evaluated as a case study based on the proposed model.

Delkhosh Kasmaei (2012) observed that a conceptual model was designed while considering four variables of "servant leadership (independent variable), organizational excellence of university (dependent variable), leader-follower relationship and organizational culture (mediating variables)".

Mirsapasi (2012) conducted a study and stated that in the path of promoting excellence, an appropriate and effective approach is the application of national quality awards. Use of national quality awards leads to improved quality, profit, processes, performance of providers, competitiveness and employee morale. A UNESCO report showed that there are 90 qualitative awards in 75 countries.

Mirsepasi demonstrated that the organizational excellence model in the public sector has ten core values which have been divided into three areas of human dignity, knowledge-based-ness and vision-based-ness.

Khodadad Hoseini (2011) suggested in a study that core excellence values comprise market orientation, social and ethical responsibility of marketing, marketing efficiency, learning and continuous improvement, focus on results, marketing value creation and also determination of marketing excellence criteria including market-oriented leadership, market analysis and understanding, marketing strategy, marketing infrastructure, marketing mix and marketing outcomes. Besides, the sub-criteria related to each of the excellence criteria were identified and conceptual relationships between them and how to realize marketing results from marketing empowerers using structural equation modeling were also determined.

Arabi (2011) showed in a study that the coordinated model of production strategy is approved and it was determined that companies with a harmonious combination of production, business and marketing strategies have better performance.

Kabaranzad Qadim (2015) showed in a study that the government's financial support from industry has not been successful from the viewpoint of successful SME managers and the rest of the aforementioned supportive policies. Evaluation of the gaps between the existing and the ideal situation disclosed that only financial support policies have been somewhat close to the ideal situation. So, attempt has been made to make the necessary suggestions using content analysis approach for the effectiveness of the future medium-term plans. 
Soltani (2010) argued that the rate of the effect of individual maturity on organizational excellence is $47.86 \%$, the rate of the effect of process maturity is $49.36 \%$ and the rate of the effect of organizational maturity is $49.44 \%$.

Zagardi (2010) demonstrated that organization size can influence the depth of implementation of information technology systems and organizational excellence model. Moreover, Iranian organizations that have widely benefited from information technology have been more successful in better application of organizational excellence model and achievement of higher scores in this model.

\section{Research methodology}

The research ontology is subjective and in terms of epistemology, the role of the researcher is immersion in the field of research and is part of the research. The research values are biased and in philosophical foundations, this research has been carried out with a "critical" notion and school of "symbolic interaction". The research method used according to the type of data is qualitative based on the grounded theory of the population structure with meta-synthesis strategy and text content analysis. Also, this research is a developmental and fundamental study in terms of conclusion and a developmental study in terms of purpose, and a sequential transformative mixed design has been used in this study.

With the aim of identifying and constructing a conceptual model of business excellence and exploratory nature of qualitative data, the qualitative research method of meta-synthesis has been used to develop the theory, which examines the information and findings extracted from other qualitative studies related to the subject. As a result, the desired sample for meta-synthesis is taken from qualitative studies selected based on their relationship with the research question (Lindgreen et al., 2004).

Content analysis is considered among the qualitative research strategies. Thus, it can be said that content analysis is applied to any inferential method that is used regularly and objectively in order to determine the features of messages. In this method, messages or information are coded and classified such that the researcher can analyze them quantitatively (Delavare, 2010).

The research data collection is based on the study of documents on a specific subject. Therefore, the examined population of the studies conducted is related to business excellence models. This population more specifically includes the models published in prestigious internal and external journals and publications. The sampling logic of this research is theoretical. Theoretical sampling based on non-limitation of samples continues until categories reach theoretical saturation. In this research, from among different views in validity measurement, the most general and most common method has been used. Long involvement: If the research has been carried out for a long time (Hooman, 2006), an agreement between two encoders is used to measure reliability, meaning that in addition to the researcher who has made the initial coding, another encoder will do this separately and without knowing the researcher's codes. If the codes of the two researchers are close together, this indicates high agreement between the two coders, which represents reliability. To calculate the coefficient of agreement between two encoders, Kappa coefficient has been employed which is equal to 0.87 in this study for 110 samples and the significant number for acceptance is 0.001; hence, the coding reliability is approved (Mosa Khani et al., 2014).

Based on the foregoing and use of meta-synthesis technique, a total of 110 excellence models were identified. To facilitate the qualitative data process using text content analysis, MAXQDA 
software has been applied. According to experts, in open coding, the researcher freely engages in naming the concepts (or codes) and does not limit the codes (Mansourian, 2006). In the next step which is called axial coding, the process of assigning code to the concepts existing in the data exits the completely open state and takes a selective form. In the final stage of coding, since the main component of the theory is gradually showing itself, the researcher acts more selectively in the coding job on the basis of these emerging components. Thereby, the final coding stage is called "selective".

\section{Research findings}

In the present study, grounded theory was used as the analysis strategy. In the first stage, metasynthesis method has been applied to compare, interpret, convert and combine different model frameworks offered in the field of business excellence. At this stage, dimensions and components (in the population under investigation) were determined and identified in databases, journals, conferences and various search engines. (Time limit) Research questions, keywords and search resources were answered to complete the research. Initially, the studies conducted on the extraction of key indicators are revealed with the aid of meta-synthesis method and literature review. Various studies have used expert opinion polls to determine key indicators. Given that in this research, access to world-class experts is not possible, Knowledge and information of authentic and international models are used as expert opinions to build the framework of key indicators. To this end, international models are initially investigated and 102 authentic models are selected with respect to the following three criteria: scientific backing of the model, frequency and experience of using the model in different countries and indicator availability.

According to the study carried out by Mirsepasi, 94 excellence models have been identified, of which 38 models have used the logic of European Quality Foundation Award, 17 models have used Malcolm Baldrige model, 2 models have used Deming Quality Award, 4 models have used European Quality Award and Baldrige, 4 models have used Deming Quality Award and Baldrige, 2 models have used Deming Quality Award, European Quality Award and Baldrige, 16 models have used a unique model, 1 model has used Australian Business Excellence Award and 10 models have used unknown models. In the following, only three major models have been considered and based on the preliminary studies, 102 business excellence models in 7 categories (strategy and organization/ finance and governance/ sales and marketing/ supply chain and logistics/ innovation and technology/ leadership, change and human resources/information technology) were identified and examined.(Table 1)

\section{Conclusion and suggestions}

In content analysis of open coding in two stages, a total of 869 concepts or open codes were initially obtained from 102 conceptual excellence models through qualitative coding. Since key indicators are those agreed by experts of the organization offering them, frequency of indicators in models is an appropriate criterion for determining the main indicators of open coding. It should be noted that the frequency of indicators in models is determined by their definitions, meaning that if the two indicators have different titles but similar definitions, then those two indicators are assumed to be the same. Afterwards, semantically common and similar concepts (initial codes) were classified in the form of 50 major categories based on frequency. In the following table, major (final) categories have been presented separately for each initial category. (Table 2) 
In the selective coding stage, the selected category and the relationship between all major categories revolving around the core category should be examined and then, the grounded model should be designed based on the story line.

Five main criteria of the model consist of people, market, underlying factors, management and work, placed on the circumference of a circle, which represents the model continuity thinking. Inside the circle is called internal business environment and its outside is called external business environment.

Criterion of people: It comprises 5 sub-criteria of staff, leadership, suppliers, partners and customer.

Criterion of market: It includes 6 sub-criteria of quality, services and products, finance, brand, marketing and competition.

Criterion of underlying factors: It covers 12 sub-criteria of skill and resources, value, knowledge, maturity, development, improvement and technology, agility, stability and innovation.

Criterion of management: It consists of 3 sub-criteria of control, organization and structure and planning and strategy.

Criterion of work: It embraces 3 sub-criteria of operation, activity and performance.

The five criteria have a causal relationship. But the more important point about the underlying criteria is that they are like a place that has the duty of receiving messages (request and need) from people and market and decoding and sending the message to management and labor. Besides, to meet the needs and requests, the existence of at least underlying sub-criteria is required and if they do not exist, they must come about. In the end, product and service are delivered to this place to investigate whether they overlap the needs and requests. The percentage of overlapping shows the rate of business excellence. (Figure 1)

At the end of the study, the following applied and research suggestions are provided with the aim of developing and applying its achievements:

- The conducted study is a small step towards the extraction of indicators and concepts of business excellence from 102 classic models. Thus, interested researchers and scholars are recommended to benefit from the rich resources of articles to extract business excellence theories with a grand theory approach.

- In this study, business excellence indicators with a grand theory approach were measured but were not tested in any specific business and statistical population. Hence, other researchers are suggested to study, evaluate and test these indicators in businesses.

- Considering that the approach used in this study is the grand theory and the model has been examined and extracted only through content analysis, it is suggested that the validity of the model be examined and analyzed for validation and operational review of the model using quantitative tests and structural equation system.

- In addition to the above cases, given that based on the conceptual model, this research is a wide variety of business excellence, it is suggested that a tool be designed for measuring business excellence and business status be compared with industry benchmarks through 
gap analysis so that a solution is proposed to reduce the distance between business and the degree of complication.

This paper has been extracted from Ph.D. thesis of Azad University in the field of commerce with marketing orientation, titled "Providing and explaining the business excellence model under study: Small and medium businesses of ICT industry in Tehran".

\section{References}

Aaker, D. A. (1996), "Measuring brand equity across products and markets", California management review, Vol. 38 No. 3, pp. 102-120.

Aaker, D. A., Equity, M. B. (1991), The Free Press. New York.

Aaker, J. L. (1997), "Dimensions of brand personality", Journal of marketing research, Vol. 34, pp. 347-356.

Adib Hajbagheri, M., Parvizi, S., Salsali, M. (2013), "Qualitative Research Methodology", Bashari Publishing and Advertising, Tehran.

Afjeh, S, A, A., Taghi Pourfar, V., Azar, A,. Jafarpour, M. (2014), "A Comprehensive Model of Organizational Justice with an Islamic Approach", Journal of Management Studies Improvement and Evolution, Vol. 23 No. 74, pp. 21-47.

Aguilar, F. J. (1967), Scanning the business environment, New York, Macmillan.

Akbari Emami, S., Mashbaki, A., Khodadad Hoseini, S, H., Kordnaij, A. (2015), "Designing the Behavior Pattern for Successful Strategy Implementation", Journal of Resource Management Research, Vol. 20 No. 1, pp. $103-130$

Albliwi, S. A., Antony, J., Arshed, N. (2014), "Critical literature review on maturity models for business process excellence". In Industrial Engineering and Engineering Management (IEEM), 2014 IEEE International Conference on, pp. 79-83.

Ambler, S. (2002), Agile modeling: effective practices for extreme programming and the unified process. John Wiley \& Sons, Inc. New York, NY, USA

American Productivity \& Quality Center (1992), APQC's Process Classification Framework (PCF).

Amir Bolboli, S., Reiche, M. (2013), "A model for sustainable business excellence: implementation and the roadmap", The TQM Journal, Vol. 25 No. 4, pp. 331 -346.

Ansoff, H. I. (1965), Corporate strategy: business policy for growth and expansion, New York: McGraw-Hill.

Arabi, S, M., Mostafavi, A. (2011), "The Integrated Model of Marketing and Business Marketing Strategies and Their Impact on Organizational Performance", Journal of Improvement Management Studies, Vol. 18 No. 64, pp. 89 -116. 
Arabshahi Karizi, A. (2014), "Presentation of Transcendental Organization Model with Emphasis on Islamic Approach Case Study: Higher Education Institutes of Mashhad". Journal of Management Process and Development, Vol. 27 No. 4, pp. 3 -24.

Asgharnejad Nouri, B., Sanaiei, A., Fathi, S., Kazemi, A. (2014), "Meta-analysis of the moderating role of sample characteristics in relation between marketing activities and organizational performance", Journal of Management Researches in Iran, Vol. 18 No. 1, pp. 151 -169.

Balbastre-Benavent, F., Canet-Giner, M. T. (2011), "The strategy formation process in the EFQM Excellence Model: a critical review and new perspectives", Total Quality Management \& Business Excellence, Vol. 22 No. 7, pp. 727 -742.

Beer, M., Bert Spector, e. a. (1984), Managing Human Assets: The Groundbreaking Harvard Business School Program, The Free Press, New York.

Beer, M. (2015), "HRM at a crossroads: Comments on Evolution of strategic HRM through two founding books: A 30th anniversary perspective on development of the field", Human Resource Management, Vol. 54 No. 3, pp. 417 -421.

Belbin, R. M. (1970), "Inspection and human efficiency", Applied Ergonomics, Vol. 1 No. 5, pp. $289-294$.

Bentley, C. (2010), Prince2: a practical handbook. Routledge.

Bernthal, P. R., Colteryahn, K., Davis, P., Naughton, J., Rothwell, W. J., Wellins, R. (2004), "ASTD competency study: Mapping the future", Alexandria, VA: ASTD.

Boston Consulting Group Matrix. (1970), available at: www.free-managementebooks.com/dldebk-pdf/fme-boston-matrix.pdf

Breally, R.A., Meyers, S. C., (1991), Principles of Corporate Finance, Fourth Edition, McGraw Hill, New York.

Bridges, W., Mitchell, S. (2000), "Leading transition: A new model for change", Leader to leader, Vol. 16 No. 3, pp. $30-36$.

British Standards Institution. (1987), British Standard Quality Systems BS 5750: Part 1, ISO 90011987, EN 29001-1987.

Buchanan, R. (1992), "Wicked Problems in Design Thinking," Design Issues, Vol. 8 No. 2

Camp, R. C. (1989), Benchmarking: The Search for Industry Best Practices that Lead to Superior Performance, Milwaukee, Wisconsin: ASQCQuality Press.

Canada National Quality Institute (1984), AWARD EXCELLENCE BUSINESS AND PUALITY Canada

Chambers, E. G., Foulon, M., Handfield-Jones, H., Hankin, S. M., Michaels, E. G. (1998), The war for talent, McKinsey Quarterly, pp. 44-57. 
Champions, H. R. (1996), "The next agenda for adding value and delivering results", Harvard Business School Press, Boston.

Christensen, C. M., Raynor, M. E., McDonald, R. (2015), "What is disruptive innovation", Harvard Business Review, Vol. 93 No. 12, pp. 44-53.

Collin, A. (1989). Managers' competence: rhetoric, reality and research. Personnel Review, Vol. 18 No. 6, pp. $20-25$.

Conger, S. (2008), IT Infrastructure Library (ITIL®).

Cooper, R. C. (1986), Winning at New Products Addisson-Wesley. Reading MA.

Cooper, R., Kaplan, R. S. (1988), "How cost accounting distorts product costs", Strategic Finance, Vol. 69 No. 10, pp. 20.

COPC Inc, (1996), Customer Operations Performance Centre. (COPC) standards.

Corbett, S. (2007), "Beyond manufacturing: The evolution of lean". McKinsey Quarterly, Vol. 3, pp. $95-96$.

Council, A. Q. (2002), Australian business excellence framework 2002: the proven vehicle to drive measurable improvement. AQC.

Covey, S. (1989), The seven habits of highly successful people, Fireside, New York: Simon \& Schuster.

Covey, S. R., Merrill, A. R., Merrill, R. R. (1995), First things first, 1st Fireside ed. New York: Simon \& Schuster.

Curry, A., Curry, J. (2002), The customer marketing method: how to implement and profit from customer relationship management, New York: Simon \& Schuster.

Curtis, D. B., Hefley, W. E., Miller, S. A. (2002), The people capability maturity model: Guidelines for improving the workforce. Addison-Wesley.

Dahgaard - park, s. M., Dahlgard, J. J. (2007), "Excellence-25 years Evolotion"،Journal of Management Histor, Vol. 13 No. 4, pp. 371-393.

De Bono, E. (1985), Six Thinking Hats: An Essential Approach to Business Management. Little, Brown, \& Company, ISBN 0-316-17791-1 (hardback) and 0316178314 (paperback). [cited 20 Feb. 15]. Available from: http://en. wikipedia. org/wiki/Six_Thinking_Hats.

Dehghani Saryazdi, M (2014), "The Effect of KM Strategies on Organizational Excellence: With the Dynamic System Approach", Ph.D. Thesis, Yazd, Technical University.

Delavare, A. (2010), Theoretical and Practical Research Fundamentals in the Humanities and Social Sciences, Tehran: Growth Publication, Eighth Edition.

Delkhosh Kasmaei, A. (2012), "The Leader Model of Servant in the Organizational Excellence of the University of Police", Ph.D. Thesis, Tehran, Allameh Tabatabaei. 
Dillon, A. P., Shingo, S. (1985), A revolution in manufacturing: the SMED system. CRC Press.

Drucker, P. F. (1995), People and performance: The best of Peter Drucker on management, Routledge.

e Sá, P. M., Kanji, G. (2003), "Leadership for excellence in the Portuguese municipalities: Critical success factors, measurements and improvement strategies", Total Quality Management \& Business Excellence, Vol.14 No.2, pp 131-139

Farzaneh, M., Issaei, M, T., Alavi, B (2014), "A Success Model for the Analysis of Agile Methodology in the Software Product Maintenance Stage from the Point of View of Software Analysts", Journal of Management Researches in Iran, Vol. 18 No. 2, pp149-181.

Feigenbaum, A. (1956), "Total Quality Control", Harvard Business Review, Vol.34 No.6, pp 93101

Fenz, S., Goluch, G., Ekelhart, A., Riedl, B., Weippl, E. (2007), "Information security fortification by ontological mapping of the ISO/IEC 27001 standard", In Dependable Computing, 2007. PRDC 2007. 13th Pacific Rim International Symposium on. pp. 381-388, IEEE.

Ford Motor Companys (1987), Eight Disciplinees Problem Solving D8 Team Oriented Problem Solving (TOPS)

Garwin, D. A. (1992), Operations Strategy: Text and Cases, Prentice-Hall, London.

Gibson, T. C. (1978), TOTAL QUALITY MANAGEMENT RESOURCE, Quality Progress Vol. 20, No. 11

Goleman, D. (1998), Working with emotional intelligence, New York, NY: Bantam Books.

Gómez-Gómez, J., Gómez-Gómez, J., Martínez-Costa, M., Martínez-Costa, M., MartínezLorente, Á. R., Martínez-Lorente, Á. R. (2016), "Weighting the dimensions in models of excellence-a critical review from a business perspective", Measuring Business Excellence, Vol. 20 No. 3, pp. 79-90.

Greiner, L. E. (1997), "Evolution and Revolution as Organizations Grow: A company's past has clues for management that are critical to future success", Family Business Review, Vol. 10 No. 4, pp. 397-409.

Hajian, A., Ahmadvand, A, M., Movahedi, M. (2013), "Performance Evaluation Model for NonIndustrial Research Organizations", Journal of Human Resources Management Research, Vol. 5 No. 2, pp. 81-105.

Hammer, M. (1990), Reengineering work: don't automate, obliterate. Harvard business review, Vol. 68 No. 4, pp. 104-112.

Hiatt, J. (2006), ADKAR: a model for change in business, government, and our community, Prosci Learning Center Publications.

Hirano, H. (1988), JIT Factory Revolution: A Pictorial Guide to Factory Design of the Future, Portland, OR : Productivity Press 
Hofstede, G. (1984), Culture's consequences: International differences in work-related values, Sage Publications, London and Beverly Hils

Holdsworth, R., Lundgaard, W. (2009), An HR intervention. HR Monthly, P, 32.

Hooman, H. A. (2006), A Practical Guide to Qualitative Research, Tehran, Publication Samt.

Hosseini Ghasr, S., Zainabadi, H, R., Alizadeh, M. (2014), "An Analysis of the Methodology and the Findings of the Researches done in the Field of Entrepreneurship and Characteristics of the Entrepreneur", Journal of Management Researches in Iran, Vol. 15 No. 4, pp. 43-63.

Humphrey, W. S. (1988), "Characterizing the software process: a maturity framework", IEEE software, Vol. 5 No. 2, pp. 73-79.

Hyder, E. B., Paulk, M. C., Heston, K. M., Hefley, B. (2010), eSourcing Capability Model for Service Providers-eSCM-SP, Van Haren Publishing.

Imai, M (1986), Kaizen: The Key to Japan's Competitive Success. New York: Random House.

Imai, M (1997), Gemba kaizen: a commonsense low-cost approach to management, New York: McGraw-Hill Professional.

International Organization for Standardization (2010), ISO 10668 Brand valuation This standard was developed by ISO technical committee ISO/TC 289.

Jahanian, S., Salehi, M, M. (2015), "Extracting Interconnected Components of Internet Marketing: A Combined Research Plan", Journal of Management Researches in Iran, Vol. 19 No. 3, pp. 61-81.

James P. W., Daniel T. J. (1997), Five Principles of Lean The Lean Enterprise Institute (LEI).

Kabaranzad Qadim, M, R., Mamaghani, A.,Timurnezhad, K. (2015), "Investigating the Impact of Government Support Policy on Small and Medium Industries in the Fourth Development Plan of the Country", Journal of Management Researches in Iran, Vol. 15, pp. 193-215.

Kanji, G. K. (1998), "Measurement of business excellence". Total Quality Management, Vol. 9 No. 7, pp. 633-643.

Kano, N., Nobuhiku, S., Fumio, T., Shinichi, T. (1984), "Attractive quality and must-be quality". Journal of the Japanese Society for Quality Control (in Japanese). 14 (2): 39-48

Kapferer, J. N. (1992), Strategic Brand Management: New Approaches to Creating and Evaluating Brand Equity, New York: Free Press

Kaplan, R. S., Norton D. P. (1992), The Balanced Scorecard: measures that drive performance. Harvard Business Review, pp. 71-80.

Keller, K. L. (1993), "Conceptualizing, measuring, and managing customer-based brand equity", Journal of Marketing, pp. 1-22. 
Keller, K, L., Kotler, P. (2006), A Framework for Marketing Management, Published by Prentice Hall

Khodadad Hoseini, S, H., Shirkhodaei, M., Ahmadi, P. (2011), "Designing the" marketing excellence "model in combined production industry", Journal of Management Researches in Iran, Vol. 15 No. 1, pp. 201-222.

Khodadad Hosseini, S, H., Khodami, S., Mashbaki, A. (2015), "Designing a Market Performance Model Based on Dynamic Marketing Features with Operational Agility Approach", Journal of Management Researches in Iran, Vol. 19 No. 3, pp. 83-112.

Kim, W.C., Mauborgne, R. (2005), Blue Ocean Strategy: How to Create Uncontested Market Space and Make the Competition Irrelevant, Boston, Harvard Business School Press. ISBN 978-1591396192.

Kotter, J. P. (1996), Leading change, Harvard Business Press.

Kraljic, P. (1983), "Purchasing must become supply management", Harvard business review, Vol. 61 No. 5, pp. 109-117.

Learned, E. P. (1969), Business policy: Text and cases. RD Irwin

Lee, P. M. (2002), "Sustaining business excellence through a framework of best practices in TQM", The TQM Magazine, Vol. 14 No. 3, pp. 142-149.

Lencioni, P. (2006), The five dysfunctions of a team. John Wiley \& Sons.

Levensaler, L., Laurano, M. (2010), Talent management systems 2010: Market realities, implementation experiences, and solution provider profile. Oakland, CA: Bersin.

Lewin, K. (1946), "Action research and minority problems", Journal of social issues, Vol. 2 No. 4, pp. 34-46.

Lindgreen, A., Palmer, R., Vanhamme, J. (2004)," Contemporary marketing practice: Theoretical propositions and practical implications", Marketing Intelligence \& Planning, Vol. 22 No. 6, pp. 673-692.

Madani, F. S. (2015), "Designing and explaining the model of customer excellence process Case Study: Banking \& Insurance Industry", Ph.D., Tehran, Tarbiat Modares.

Mansourian,Y. (2006), Adoption of grounded theory in LIS research New Library World, Vol. 9 No. 10, pp. 386-402.

Masaaki, I. (1986), Kaizen: The key to Japan's competitive success, New York, ltd: McGraw-Hill.

McCarthy, E. J. (1960), Basic Marketing: A Managerial Approach. Richard D. Irwin, Inc.

McKinsey and General Electric (GE), Inc. (2000). Boston Consulting Group share/growth matrix 
Mesquida, A. L., Mas, A., Amengual, E., Calvo-Manzano, J. A. (2012), "IT Service Management Process Improvement based on ISO/IEC 15504: A systematic review", Information and Software Technology, Vol. 54 No. 3, pp. 239-247.

Millward, B. (2006),"Brand Dynamics Pyramid", "Brand Management Models".

Mirabile, R. J. (1997), "Everything you wanted to know about competency modeling", Training \& Development, Vol. 51 No. 8, pp. 73-78.

Mirsapasi, N., Memarzadeh, G., NajafBeigi, M., Alizadeh, M. (2012), "Recognizing the criteria of excellence in the public sector", Journal of Management of Governmental Organizations, Vol. 4 No. 2, pp. 70-53.

Mitchell, R. K., Agle, B. R., Wood, D. J. (1997), "Toward a theory of stakeholder identification and salience: Defining the principle of who and what really counts", Academy of management review.

Mosa Khani, M., Manian, A., Ahgaqi, E. (2014), "Developing a Model for Assessing Collaboration Maturity in Shabab Network Interagency Networks", Journal of Management Researches in Iran, Vol. 18 No. 3, pp. 157-180.

Mycle, S., Henrry, R. (2004), Business Excellence Diamond Model.

Nabitz, U. W., Klazinga, N. S. (1999), "EFQM approach and the Dutch Quality Award", International Journal of Health Care Quality Assurance, Vol. 12 No. 2, pp. 65-71.

Nakajima, S. (1988), Introduction to TPM: Total Productive Maintenance. (Translation), Productivity Press, Inc. pp. 129.

National Institute of Standards and Technology (NIST) (1987), available at: https://www.nist.gov/image-21327

Nolan, R. L., Croson, D. C. (1995), Creative destruction: A six-stage process for transforming the organization, Harvard Business Press.

O'Rourke, D. (2000), "Monitoring the monitors: a critique of PricewaterhouseCoopers (PwC) Labor Monitoring", Department of Urban Studies and Planning Massachusetts Institute of Technology.

Ofman, D. (2004), Core Qualities: A Gateway to Human Resources, Cyan Communications.

Ohmae, K. (1989), "The global logic of strategic alliances", Harvard business review, Vol. 67 No. 2, pp. 143-154.

Ohno, T. (1988), Toyota production system: beyond large-scale production. crc Press.

Osterwalder, A., Pigneur, Y. (2010), Business model generation: a handbook for visionaries, game changers, and challengers, John Wiley \& Sons.

Parasuraman, A., Zeithaml, V. A., Berry, L. L. (1988), "Servqual: A multiple-item scale for measuring consumer perc", Journal of retailing, Vol. 64 No. 1, pp. 12. 
Pearce, D. W., Turner, R. K. (1990), "Economics of natural resources and the environment, Baltimore MD: Johns Hopkins University Press", Available at: http://hdl.handle.net/10.2307/1242904 (application/pdf)

Pena, E. D. (1990), Motorola's secret to total quality control, Quality Progress, Vol. 23, No. 10

Perrier, R. (1997), Interbrand. Brand Valuation. London: permier books, pp.43-53.

Porter, M. E. (2008). "The five competitive forces that shape strategy", Harvard business review, Vol. 86 No. 1, pp. 25-40.

Porter, M. E., Millar, V. E. (1985), How information gives you competitive advantage, New York: Free Press,

Project Management Institute (1987), "Project Management Body of Knowledge (PMBOK) ", Project Management Institute.

Rastgar, A, A., Kahiyari Haghighat, A., Kahiyari Haghighat, M. (2016), "Designing a Brand Performance Model in Industrial Markets", Journal of Resource Management Researches, Vol. 6 No. 1, pp. 71-103.

Ross, S.A., Water Field, R.W., Jaffe, J. F. (1991), Corporate Finance, Toppan Co. Ltd.

Rothwell, W. J., Arneson, J., Naughton, J. (2013), "ASTD competency study: The training \& development profession redefined", American Society for Training and Development.

Schwaber, K (2004), Agile Project Management with Scrum, Microsoft Press. ISBN 978-0-73561993-7.

Searle, M. (2005), presentation by SAI Global, 13th Quality Summit of CII, India, pp. 10-11.

Senge, P. (1990), The fifth discipline Doubleday, New York.

Senge, P. M. (2014), The fifth discipline fieldbook: Strategies and tools for building a learning organization, Crown Business.

Sharma, K., Talwar, B. (2007),"Evolution of Universal Business Excellence in Corporate vedic Philosophy", Measuring Business Excellence, Vol. 11 No. 3, pp. 4-20.

Shingo Institute (1988), Leading a New Era of Enterprise Excellence, shingo.org.

Shingo, S., Dillon, A. P. (1989), A study of the Toyota production system: From an Industrial Engineering Viewpoint, Cambridge, Mass. Productivity Press, (O1989.

Soltani, I., Bahraminihad Junaghani, R. (2010), "The Impact of Organizational Maturity on Organizational Excellence in Mobarakeh Steel Company", Journal of Management Improvement and Management Studies, Vol. 17 No. 62, pp. 163-193.

T. O. G. A. F. (2009), the open group architecture framework (togaf). The Open Group 
Team, C. P. (2002), Capability Maturity Model® Integration (CMMI), Version 1.1--Continuous Representation.

The Information Systems Audit and Control Association (ISACA) (1998), Control Objectives for Information and Related Technology (COBIT)

Treacy, M., Wiersema, F. (1993), "Customer intimacy and other value disciplines", Harvard business review, Vol. 71 No. 1, pp. 84-93.

Tuckman, B. W. (1965), "Developmental sequence in small groups", Psychological bulletin, Vol. 63 No. 6, pp. 384.

Ulrich, D., Brockbank, W. (2005), The HR value proposition, Harvard Business Press.

Ulrich, D., Brockbank, W., Johnson, D., Younger, J. (2007), "Human resource competencies: Responding to increased expectations", Employment Relations Today, Vol. 34 No. 3, pp. 112.

Ulrich, D., Smallwood, N., Sweetman, K. (2009), The leadership code: five rules to lead, Harvard Business Press.

Ulrich, D., Younger, J., Brockbank, W., Ulrich, M. (2012), HR from the outside in: Six competencies for the future of human resources, New York: McGraw-Hill.

United States Department of War (1945), Training Within Industry (TWI) within the War Manpower Commission

Waterman, R. H., Peters, T. J., Phillips, J. R. (1980), "Structure is not organization", Business horizons, Vol. 23 No. 3, pp. 14-26.

Wright, L.T. (2008), 'Qualitative Research' in Baker, M. and Hart, (eds), The Marketing Textbook, Elsevier, 6thedition, Chapter 9, pp. 156-169.

Yoji, A. (2004), Hoshin Kanri: Policy deployment for successful TQM. Steiner Books.

Young and Rubicam (2000), BAV Brand Asset Valuator white paper Retrieved from the Internet: accessed: December http://www.yr.com/knowledge/YR-BAV_white_paper.pdf

Zagardi, H., Esmaeili, M., (2010), "Influence of Information Technology on Excellence in Iranian Organizations", Management Researches in Iran, No. 2, pp. 61. 